for providing the specimens. This work was supported by a grant from the US Public Health Service.

Scripps Institution of Oceanography,

University of California, San Diego,

La Jolla, California.

Received September 30, 1969.

${ }^{1}$ Warren, H. V., and Delavault, R. E., Trans. Roy. Soc. Chem., Sect. III, 54, i1 (1960).

${ }^{2}$ Cannon, H. L., and Bowles, J. M., Science, 13\%, 765 (1962).

${ }^{3}$ Miurozumi, M., Chow, 'T. J., and Patterson, C. C., Geochim. Cosmochim. Acta, 33, 1247 (1969).

4 Chow, T. J., and Johnstone, M. S., Science, 147, 502 (1965).

\section{Rates of Evolutionary Change in the Hominid Canine Teeth}

Rates of evolutionary change in the size and shape of hominid cheek teeth were not constant during tho Pleistocene'. Because of the widespread interest in the relationship between the use of tools and the evolution of human canine teeth, I now present data for rates of evolutionary change in hominid canines. Evolutionary rates should be rapid at times of strong selective pressure for larger or smaller canines. My data, however, do not support the orthodox view ${ }^{2}$ that a reduction in size of the canine accompanied the appearance or carly development of tool making by the precedessors of man.

The earliest hominid for which dental measurements and reliable estimate of age aro available is the Ramapithecus maxilla from Fort Ternan, Kenya. The material has been dated by K/Ar at 14 million years ${ }^{3}$. Although there is disagreement about the taxonomic status of the Fort Ternan specimens, it is generally agreed that Ramapithecus, including the closely similar Asian material ${ }^{4}$, is a reasonable ancestor for later horninid forms.

Younger fossil hominids (the oldest known australopithecines) have been reported from Omo Basin, Ethiopia. A mandibular fragment including a canine belonging to Australopithecus was obtained from locality 74 immediately below a layer dated at $1.87 \mathrm{~m} . \mathrm{y} \cdot{ }^{5}$. The estimated age of this hemimandible was placed at $2 \cdot 0 \mathrm{~m} . \mathrm{y}$. Further fossil hominids of known age for which canine and premolar measurements were available included the Homo erectus (Pithecanthropus IV) maxilla from Java ${ }^{6}(700,000$ yr), and the Homo erectus material from Choukoutien (Pekin), China ${ }^{7}(370,000 \mathrm{yr})$. The dates are as given by Bilsborough ${ }^{1}$, as are the parameters for teeth of Homo sapiens derived from the average of values for Australian aborigines ${ }^{8}$ and African bushmen ${ }^{9}$. A phylogenetic series of hominid dentitions is thus provided from before the known existence of stone tools to the present-a period of $14 \mathrm{~m} . \mathrm{y}$.

The mesiodistal $(M D)$ and buccolingual $(B L)$ dimensions, shape index (100 BL/MD), and crown size $(M D \times$ $B L$ ) were calculated to provide comparisons with previous data on premolars and molars". Canine-premolar ratios (100 $C / P^{4}$ ) were also calculated for the module $(M D+$ $B L / 2$ ), and for crown size; the validity of these comparisons was demonstrated by Tobias ${ }^{10}$.

Evolutionary rates were calculated according to Haldane's formula ${ }^{11}$

$$
\text { Rate of change }=\frac{\log _{e} x_{2}-\log _{e} x_{1}}{t_{2}-t_{1}}
$$

where $x_{1}$ and $x_{2}$ are the mean values for a parameter at times $t_{1}$ and $t_{2}$. Rates were expressed in millidarwins (one darwin is an increase or decrease in a parameter by a factor of $e$ per m.y.).

Rates of change in the hominid canines and caninopremolar ratios are presented in. Tables 1 and 2. Before Homo erectus appesured in the Middle Pleistocene, the rate of change was low in all parameters. It was loss than 50
Table 1. RATES OF EVOLCTIONARY CHANGE OF HOMINID YAXILLARY CASINF

\begin{tabular}{|c|c|c|c|}
\hline Interval & & Parameter & Rute \\
\hline $\begin{array}{l}\text { Ramapithecus (Fort Tcrnan)-IIomo } \\
\text { ereetus (Java) (13-3 m.y.) }\end{array}$ & $\begin{array}{l}M D \\
B I \\
I \\
A \\
C / P^{4} M \\
C / P^{4} A\end{array}$ & $\begin{array}{r}9 \cdot 25-9 \cdot 5 \\
8 \cdot 0-11 \cdot 8 \\
86 \cdot 5-124 \cdot 2 \\
74 \cdot 0-112 \cdot 1 \\
106 \cdot 2-103.4 \\
120 \cdot 3-109 \cdot 6\end{array}$ & $\begin{array}{r}+2 \\
+29 \\
+27 \\
+31 \\
-2 \\
-7\end{array}$ \\
\hline $\begin{array}{l}\text { Homo erectus (Java)-Homo erectus } \\
\text { (Pekin) }(0.33 \text { m.y.) }\end{array}$ & $\begin{array}{l}M D \\
B L \\
I \\
A \\
C / P^{4} M \\
C / P^{4} A\end{array}$ & $\begin{array}{r}9.5-9 \cdot 4 \\
11 \cdot 8-10 \cdot 2 \\
124 \cdot 2-107 \cdot 6 \\
112 \cdot 1-95 \cdot 7 \\
103.4-101 \cdot 5 \\
109 \cdot 6-106 \cdot 3\end{array}$ & $\begin{array}{r}-22 \\
-456 \\
-434 \\
-479 \\
-56 \\
-94\end{array}$ \\
\hline $\begin{array}{l}\text { Homo erectus (Pekin)-Homo sapiens } \\
(0.37 \mathrm{m.y} .)\end{array}$ & $\begin{array}{l}M D \\
B L \\
I \\
A \\
C / P^{4} \mathrm{M} \\
C / P^{4} A\end{array}$ & $\begin{array}{r}9 \cdot 4-8 \cdot 0 \\
10 \cdot 2-8 \cdot 4 \\
107.6-105.5 \\
95.7-66.9 \\
101.5-101 \cdot 1 \\
106.3-104 \cdot 6\end{array}$ & $\begin{array}{r}-456 \\
-511 \\
-55 \\
-987 \\
-10 \\
-43\end{array}$ \\
\hline
\end{tabular}

Table 2. RATES OF EVOLUTIONARY OHANGE OF HOMIXIn MaNDIBUTAR CANINE TKETH

$\begin{array}{clrr}\text { Interval } & & \text { Parameter } & \text { Rate } \\ \text { Australopithecus (Omo)-Homo erec- } & M D & 8 \cdot 8-8 \cdot 6 & -16 \\ \text { tus (Pekin) (1.63 m.y.) } & B L & 8 \cdot 7-8 \cdot 2 & -32 \\ & I & 110 \cdot 2-107 \cdot 4 & -16 \\ & A & 85 \cdot 4-78 \cdot 9 & -48 \\ \text { Homo erectus (Pekin)-Homo sapiens } & M D & 8 \cdot 6-7 \cdot 2 & -470 \\ \text { (0.37 m.y.) } & B L & 9 \cdot 2-7 \cdot 7 & -498 \\ & I & 107 \cdot 4-106 \cdot 3 & -29 \\ & A & 79 \cdot 1-55 \cdot 1 & -968\end{array}$

$M D=$ mesiodistal diameter $; \quad B L=$ buccolingual diameter $\quad I=$ shape index: $A=$ crown area.

millidarwins even for reduction in canine size before $700,000 \mathrm{yr}$ ago. Low rates of change for premolars and molars were also obtained ${ }^{1}$ for the Lower Pleistocene.

Not until the Middle Pleistocene, when the process of tool making had become a highly refined skill associated with specialized lithic industries, was the rato of roduction in canine size rapid. From Homo erectus at Choukoutien to $H$. sapiens the rate of decrease in both upper and lower canines was nearly 1 darwin, while the change in shape and in relative size was negligible. Strongly selective factors clearly produced markedly rapid reduction in absolute size of the canine from $H$. erectus to $H$. sapiens, and at rates comparable with those for reduction of the upper and lower promolars ${ }^{1}$ during the same time period.

Before, and perhaps during, the time of rudimentary tool development in the Pliocene, and during the time of primitive pebble tool use in the Early Pleistocene wher, according to the orthodox view, the canine should havo been responding to strong selective pressure, the rate of change was at its lowest.

These data suggest that the development of tool making among the earliest hominids was not associated with rapid change in size and shape of the canine teeth.

When rapid dental reduction finally occurred during and after the Middle Pleistocene, it seems to have come about as a result of factors other than the development of tool making.

\section{W. G. KINZEY}

Department of Anthropology,

University of California,

Davis, California 95616

Received October 24, 1969 .

${ }^{1}$ Bilsborough, A., Nature, 223, 146 (1969).

2 Washburn, S. L., Scientific American, 253, 62 (1960).

${ }^{3}$ Leakey, L, S. B., Ann. Mag. Nat, Hist., 4, 689 (1962).

${ }^{1}$ Simons, E. L., S. Afric. J. Sci., 64, 92 (1968).

"Howell, F. C., Nature, 223, 1234 (1969).

${ }^{6}$ Weidenreich, F., Anthrop. Pap. Amer. Mus., 40, 1 (1945).

'Weidenreich, F., The Dentition of Sinanthropus Pekinensis, Palaeontologica Sinica (NS Di, Pekin, 1937).

${ }^{8}$ Campbell, T. D., Dentition and Palate of the Australiun Aboriginal (Publ. Keith Sheridan Foundation Medical Research 1, Adclaido, 1925).

o Drennan, M. R. Amm. S. Afric. Mus., 24, 61 (1929).

${ }_{10}$ Tobias, P. V., The Cranium and Maxillary Dentition of A ustralopithecus (Zinjanthropus) boisei (Cambridge Univ. Press, 1967).

1 Haldane, J. B. S., Evolution, 3, 51 (1949). 